\title{
Managing major diseases of tomato (Solanum lycopersicum L.) using resistance elicitors and protected cultivation
}

\author{
Lucia M Borines ${ }^{1 *}$, Rezel M. Sagarino', Fely R. Cañete', Elvira L. Oclarit', \\ Zenaida C. Gonzaga ${ }^{2}$, Sandra McDougall and Len Tesoriero ${ }^{2}$
}

\begin{abstract}
Diseases, particularly bacterial wilt caused by Ralstonia solanacearum is a major constraint to vegetable production. Protected cultivation has been proven effective in reducing disease incidence but additional control measures need to be integrated in highly infested soils to mitigate the losses due to diseases. This paper reports the effect of resistance elicitors, particularly chitosan, acetylsalicylic acid and $\mathrm{SiO} 2$ in mitigating bacterial wilt disease problem and other naturally occurring diseases in two field trials. Two hundred ppm chitosan, acetylsalicylic acid and their combination had reduced bacterial wilt incidence and increased the yield of tomato under protected cultivation, but not in the open field. SiO2 was not able to reduce bacterial wilt incidence in tomato but had reduced the nematode count, especially Rotylenchulus sp. in the roots, particularly when drenched. Protected cultivation still proved effective in reducing bacterial wilt incidence in both experiments. It's potential to protect crops against bacterial wilt is further enhanced by the application of chitosan and acetylsalicylic acid, most especially the combination of these treatments. The potential of chitosan and acetylsalicylic acid in protecting plants in the open field against bacterial wilt may be enhanced by the addition of a sticker.
\end{abstract}

Keywords: Chitosan, acetylsalicylic acid, $\mathrm{SiO} 2$ Control resistance booster

\section{INTRODUCTION}

Plant diseases are a continual problem in agricultural production and can inflict serious crop losses during production. Among the major diseases affecting tomato are bacterial wilt caused by Ralstonia solanacearum and leaf mold caused by Pseudocercospora fuligena. Nematode diseases are also common. Bacterial wilt

${ }^{1}$ Visayas State University, Visca, Baybay City, Leyte, Philippines

${ }^{2}$ Department of Primary Industries (DPI), Australia, NSW, Australia

* Corresponding Author. Address: Department of Pest Management, Visayas State University, Visca, Baybay City, Leyte, 6521-A Philippines; Email: lucyborines@vsu.edu.ph DOI: $10.32945 /$ atr39sb3.2017 
in particular have caused significant economic losses which is greater for tomatoes than in any other crop particularly with high rainfall (Hayward 1991). The disease is difficult to control due to its genetically diverse soil borne pathogen with a wide host range (Champoiseau, Jones \& Allen 2009).

Bacterial wilt occurs in most warm tropical and subtropical countries and is a significant problem in Eastern Visayas, Philippines with type 2 climate (characterized by having no dry season but a pronounced maximum rainfall from November to January in the Eastern Part), and Type IV (characterized by even distribution of rainfall the year round and a short period of dry season that can be observed starting February up to May (Arkipelago 2016).

No single method has shown $100 \%$ efficiency in controlling the disease. An integrated management strategy needs to be done for its management. A combination of general control methods, including host resistance, cultural practices, and the use of chemical or biological control in an integrated pest management approach is advised (Momol et al 2000).

Off season production of tomato has been uneconomical when field grown due mainly to the occurrence and high incidence of diseases favoured by too much rain. Protected cultivation using low-cost protective structures, however have made offseason production of tomato possible and economical (Gonzaga et al 2013). Protected cultivation protects the plants from too much rain. Disease incidence under protected cultivation, particularly bacterial wilt incidence is minimized in vegetables grown under protective structure (Borines et al 2016).

In soils that are highly contaminated with the bacterial wilt pathogen, protected cultivation alone may not be sufficient to reduce the damage of this disease. Furthermore, some farmers may not be able to afford the cost of the protective structure such that alternative control strategies need to be discovered.

Resistance elicitors had been reported to protect plants against disease. Some studies have shown that Silicon for example is effective in controlling diseases caused by both fungi and bacteria in different plant species. Studies of Dannon \& Wydra (2004) revealed that silicon amendment significantly reduced bacterial wilt incidence expressed as area under disease progress curve for tomato genotypes. Silicon alleviates abiotic stresses by increasing the resistance of plants to pathogenic fungi (Fauteux et al 2005). Silicon increases rice resistance to leaf and neck blast, sheath blight, brown spot, leaf scald and stem rot (Datnoff \& Rodrigues 2005).

Chitosan, a polymer of $-1,4$ glucosamine residues which is a deacetylated derivative of chitin is another resistance booster. It is extracted from exoskeletons of crustaceans and insects and which is also reported to have direct antimicrobial properties aside from being a potent elicitor of resistance in plants (Amborabe et al 2008). Chitosan was proven effective in controlling numerous pathogenic fungi, including root and necrotrophic pathogens, such as Fusarium oxysporum, Botrytis cinerea, Monilinia laxa, Alternaria alternata and Pythium aphanidermatum (EI Hassni et al 2004, Benhamou 1992, Soleimani \& Kirk 2011, El Ghaouth et al 1994, Romanazzi et al 2002, Ait Barka et al 2004 \& Lafontaine et al 1996).

It was also reported to induce resistance in plants against bacterial diseases such as potato scab caused by Streptomyces scabies (Vruggink 1970), bacterial wilt in tomato (Algam et al 2010), Agrobacterium tumefaciens (Rabea et al 2009) and poinsettia leaf spot caused by Xanthomonas axonopodis (Li et al 2008). Local researchers also demonstrated the ability of chitosan to control heart rot disease of 
abaca (Musa textilis Nee) caused by Pectobacterium chrysanthemi (Niño 2009) bacterial blight of rice caused by Xanthomonas oryzae pv. oryzae (Modina, Calibo \& Borines 2009), rice blast caused by Magnaporthe grisea (Piamonte 2010) and Ralstonia solanacearum in tomato in in vitro and pot experiment (Borines et al 2015).

Acetyl salicylic acid (Aspirin) on the other hand is another known elicitor reported to induce systemic acquired resistance to some plants, protecting them against microbial attack (Agrios 2012). Piamonte (2010) found that 50ppm of acetylsalicylic acid was more effective in reducing rice blast severity compared to 100 and $150 \mathrm{ppm}$.

Despite the several works conducted towards the management of vegetable diseases, the control of bacterial wilt is still very difficult such that the search for an effective management strategy is a continuous endeavour. Breeding for disease resistance has not been very successful because of the extensive variability of bacterial strains and the interactions of a myriad of biotic and abiotic factors. Commercial chemicals which include antibiotics, fertilizers, and fungicides have been already tested as control but without much success (Elphinstone \& Hartman 1992). Resistance boosters may be tried towards its management.

This paper reports on the evaluation of three known resistance elicitors namely: chitosan, and acetylsalicylic acid and SiO2against bacterial wilt disease of tomato grown under open and protective cultivation.

\section{MATERIALS AND METHODS}

Field trials on the effect of chitosan, acetylsalicylic acid and SiO2 on bacterial wilt of tomato and other naturally occurring diseases were conducted from March 2014 to November 2015 in the experimental area the Visayas State University. The field is known to be highly infested with bacterial wilt pathogen based on previous cropping in the area.

\section{Effect of Chitosan, Acetylsalicylic Acid and Streptomycin on Naturally Occurring Diseases of Tomato}

A $5 \mathrm{mx} 40 \mathrm{~m}\left(200 \mathrm{~m}^{2}\right)$ area both in the open field and under a low- cost protective structure was plowed and harrowed and three long raised beds were prepared running along the length of the plots. The three long plots were divided into four subplots across with each subplot serving as a block.

Tomato seeds, var. "Diamante Max" were pre-germinated in the nursery for 17 days and were hardened outside nursery for one week before transplanting. Seedlings were transplanted to the plots with a distance of $50 \mathrm{~cm} \times 50 \mathrm{~cm}$ per seedling per hill. Drip irrigation was used for watering the plant. Complete fertilizer (16-16-16) was applied as basal with a rate of $10 \mathrm{~g}$ per hill mixed with $50 \mathrm{~g}$ carbonized rice hull. Calcium Nitrate $(150 \mathrm{~g}$ per $16 \mathrm{~L})$ was also drenched at $150 \mathrm{~mL}$ per hill until flowering stage. A combination of $16-16-16$ (150g per $16 \mathrm{~L}$ ) and $0-0-60$ $(150 \mathrm{~g}$ per $16 \mathrm{~L}$ ) with a ratio of $2: 1$ were applied at fruiting stage at $150 \mathrm{~mL}$ per plant.

Two hundred ppm each of chitosan, acetylsalicylic acid (Aspirin), streptomycin, and combination of chitosan + aspirin and chitosan + streptomycin were applied as weekly spray to the plants. The specific treatments were: T0-untreated (-control), 
Managing major diseases of tomato

T1-Chitosan, T2-acetylsalicylic acid, T3-Chitosan + acetylsalicylic acid, T4-Chitosan + Streptomycin and T5-Streptomycin (+ control). The treatments were sprayed until the onset of fruiting. There were eight plants per replicate per treatment and 4 border plants were provided. The experiment was laid out in Split Plot Design with four replications per treatment.

The data gathered include horticultural characteristics such as number of days to: $50 \%$ flowering, $50 \%$ fruiting, to first and last harvest, plant height at flowering stage; weekly disease incidence (\% infection) and severity using a disease score used by Ayana and Wydra (2011) as follows: 0-no infection, 1-one leaf wilted, 2-two leaves wilted, 3-three leaves wilted, 4-wilting of all leaves without the tip and 5wilting of the whole plant; and yield such as: number and weight of marketable and non-marketable fruits.

\section{Evaluation of $\mathrm{SiO}_{2}$ Against Naturally Occurring diseases of tomato}

The same area of $200 \mathrm{~m}^{2}(5 \mathrm{~m} \times 40 \mathrm{~m})$ in an open field and under protective structure used in the previous experiment was used. Three long raised beds were prepared running along the length of the plots. The three long plots were divided into four subplots across with that served as the 4 blocks.

The same variety "Diamante Max" were pre-germinated in the nursery using the same procedure as in the previous experiment and transplanted to plots at $50 \mathrm{~cm}$ distance per hill. The fertilization scheme of the previous experiment was also followed.

Two hundred ppm (200ppm) of $\mathrm{SiO}_{2}$ was applied by drenching (T1), spraying (T2), drenching and spraying (T3) and water applied (control) at weekly interval. Sixteen plants were used as test plants per treatment and 4 plants at each end served as a buffer. The treatments were laid out in Split plot in Randomized Complete Block Design with four replications per treatment. Disease occurrence and incidence, selected horticultural parameters and yield and yield components were the data gathered.

\section{RESULTS AND DISCUSSION}

\section{Evaluation of Chitosan, Acetylsalicylic Acid and Streptomycin Against Naturally Occurring Diseases of Tomato}

\section{A. Effect of treatments on horticultural parameters}

The chitosan, acetylsalicylic acid and streptomycin treatments showed no effect on the number of days from transplanting to $50 \%$ flowering, $50 \%$ fruiting, and first harvest. The number of days to last harvest was however higher in tomato plants grown under protective structure compared to tomatoes grown in the open field (Figure 1). The longer production period of plants grown under protected cultivation consequently resulted to higher marketable fruits and more number of fruits produced. 


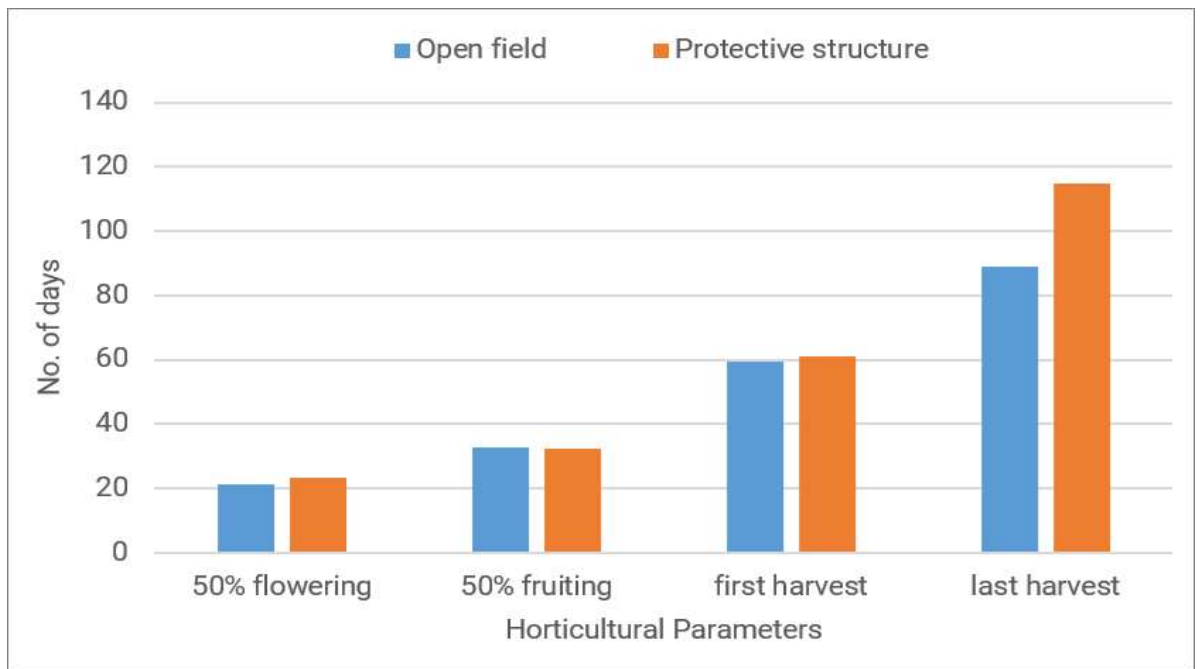

Figure 1. No. of days to flowering, fruiting, first and last harvest between 2 cultivation conditions

\section{B. Effect of treatments on disease Incidence and severity}

Two diseases had affected the tomato plants in this trial, ie, bacterial wilt caused by Ralstonia solanacearum and leaf mold caused by Pseudocercospora fuligena. The bacterial wilt incidence was very high (as high as $94 \%$ in the open field; Table 1). The different treatments were effective in reducing bacterial wilt incidence but only in tomatoes grown under protected cultivation (Table 1). All treatments, ie, chitosan, acetyl salicylic acid, streptomycin and their combination produced lesser bacterial wilt incidence compared to untreated plants although only Acetylsalicylic acid alone and + chitosan acetylsalicylic acid was significantly lesser. The disease severity ratings of individual plants did not vary significantly between elicitors. The bacterial wilt incidence were much higher in plants grown in the open field $(88 \%)$ than plants grown inside protective structure (33\%).

Table 1. Bacterial wilt incidence and severity in tomatoes sprayed with chitosan, acetylsalicylic acid, streptomycin and combination

\begin{tabular}{lcccc}
\hline \multirow{2}{*}{ Treatments } & \multicolumn{2}{c}{ Disease Incidence (\%) } & \multicolumn{2}{c}{ Disease Severity Rating } \\
\cline { 2 - 5 } & Open Field & $\begin{array}{c}\text { Protected } \\
\text { Cultivation* }\end{array}$ & Open Field & $\begin{array}{c}\text { Protected } \\
\text { Cultivation }\end{array}$ \\
\hline Untreated (- control) & 94.0 & $60.0^{\mathrm{a}}$ & 4.76 & 2.48 \\
Chitosan & 82.0 & $28.0^{\mathrm{ab}}$ & 4.28 & 1.14 \\
Acetylsalicylic acid (Aspirin) & 94.0 & $24.0^{\mathrm{b}}$ & 4.84 & 1.12 \\
Chitosan + Aspirin & 82.0 & $26.0^{\mathrm{b}}$ & 4.42 & 1.16 \\
Chitosan + Streptomycin & 90.0 & $28.0^{\mathrm{ab}}$ & 4.60 & 1.34 \\
Streptomycin (+ control) & 86.0 & $34.0^{\mathrm{ab}}$ & 4.18 & 1.62 \\
\hline Mean** & $88.0^{\mathrm{A}}$ & $33.3^{\mathrm{B}}$ & 4.51 & 1.48 \\
\hline CV (\%) & 20.0 & 32.0 & 13.2 & 39.3 \\
\hline
\end{tabular}

*Means within the column followed by same small letters are not significantly different at $5 \%$ Tukey's HSD

**Means within the row followed by same big letters are not significantly different at $5 \%$ Tukey's HSD 
Managing major diseases of tomato

A high incidence of leaf mold was also observed affecting tomato in this trial. The treatments showed no significant effect on the leaf mold incidence in the open field. Under protected cultivation, however, the plants sprayed with the combination of chitosan and streptomycin produced significantly lesser leaf mold incidence (Table 2). In both areas, plants sprayed with chitosan plus streptomycin produced significantly lower leaf mold disease severity rating.

Table 2. Leaf mold incidence and severity in tomatoes sprayed with chitosan, acetylsalicylic acid, streptomycin and combination

\begin{tabular}{lcccc}
\hline & \multicolumn{2}{c}{ Disease Incidence* $\%$ ) } & \multicolumn{2}{c}{ Disease Severity Rating* } \\
\cline { 2 - 5 } Treatments & Open Field & $\begin{array}{r}\text { Protected } \\
\text { Cultivation }\end{array}$ & Open Field & $\begin{array}{c}\text { Protected } \\
\text { Cultivation }\end{array}$ \\
\hline Untreated (- control) & 94.0 & $70.0^{\mathrm{a}}$ & $2.8^{\mathrm{a}}$ & $1.1^{\mathrm{a}}$ \\
Chitosan & 86.0 & $66.0^{\mathrm{a}}$ & $2.2^{\mathrm{ab}}$ & $1.0^{\mathrm{a}}$ \\
Acetylsalicylic acid (Aspirin) & 92.0 & $68.0^{\mathrm{a}}$ & $2.9^{\mathrm{a}}$ & $1.1^{\mathrm{a}}$ \\
Chitosan + Aspirin & 86.0 & $68.0^{\mathrm{a}}$ & $2.6^{\mathrm{ab}}$ & $1.1^{\mathrm{a}}$ \\
Chitosan + Streptomycin & 80.0 & $40.0^{\mathrm{b}}$ & $2.1^{\mathrm{b}}$ & $0.6^{\mathrm{b}}$ \\
Streptomycin (+ control) & 86.0 & $65.8^{\mathrm{a}}$ & $2.2^{\mathrm{ab}}$ & $0.9^{\mathrm{a}}$ \\
\hline Mean*(Cultivation Condition) & $87.3^{\mathrm{A}}$ & $62.96^{\mathrm{B}}$ & $2.47^{\mathrm{A}}$ & $0.97^{\mathrm{B}}$ \\
\hline CV (\%) & 12.02 & 12.5 & 7.0 & 7.9 \\
\hline
\end{tabular}

${ }^{\star}$ Means within the column followed by same small letters are not significantly different at $5 \%$ Tukey's HSD

**Means within the row followed by same big letters are not significantly different at $5 \%$ Tukey's HSD

\section{Effect of treatments on yield}

Among the yield parameters evaluated (mean number, weight of marketable \& non-marketable fruits, mean polar \& equatorial diameter of fruits), significant difference between elicitor treatments was only observed in the weight of marketable fruits, and only in plants grown under protected cultivation. Based on marketable yield results, all the elicitors and their combination had produced higher marketable yield in tons per hectare compared to untreated plants. The highest yield (41.45 $\left.\mathrm{ha}^{-1}\right)$ was produced by the chitosan+acetylsalicylic acid treatment (Table 3). This was followed by acetylsalicylic acid alone, chitosan alone and the combination of chitosan+ aspirin. The mean weight of marketable fruits was also higher in plants under protected cultivation (34.43t ha $\left.{ }^{-1}\right)$ than in the open field (14.7t $\mathrm{ha}^{-1}$ ). Furthermore, tomato fruits in plants grown under protective structure had higher polar and equatorial diameter (Figure 4).

Protected cropping had also produced higher yield in tomato. Plants grown under protective structure produced higher mean fruit weight, more and larger fruits compared to plants grown in the open field (Figure 4). Harada et al (1995) reported that application of chitosan in the field increased shoot growth, branch length, node number per plant and seed yield of soybean and total root length per plant increased by chitosan application in the pot experiment. Chibu and Shibayama (1999) reported that chitosan at 0.1 or $0.5 \%$ increased leaf area, leaf dry weight and leaf length of soybean, lettuce and rice whereas chitosan at $0.1 \%$ showed positive effects on leaf area, leaf length and dry weight of tomato.

The higher yield of tomato that were sprayed with chitosan and acetylsalicylic acid in tomato plants grown under protective cultivation is apparently due to the combined benefits of the elicitor treatments and protected cultivation. The most probable reason why the different elicitors did not show disease control and had not increase the marketable yield of tomato in open field cultivation is most likely due to 
frequent rains that had washed off the treatments since no sticker was added to the treatments.

Table 3. Marketable fruit weight of tomatoes sprayed with chitosan, acetylsalicylic acid, streptomycin and combination under open and protected cultivation

\begin{tabular}{lcc}
\hline \multirow{2}{*}{ Treatments } & \multicolumn{2}{c}{ Marketable fruit weight $\left(\mathrm{t} \mathrm{ha}^{-1}\right)$} \\
\cline { 2 - 3 } & Open field & Protective structure \\
\hline Control & 18.36 & $25.31^{\mathrm{c}}$ \\
Chitosan & 20.64 & $36.19^{\mathrm{ab}}$ \\
acetylsalicylic acid & 19.90 & $36.40^{\mathrm{ab}}$ \\
Streptomycin & 16.96 & $33.46^{\mathrm{b}}$ \\
Chi+ acetylsalicylic acid & 15.97 & $41.45^{\mathrm{a}}$ \\
Chi+ Streptomycin & 19.18 & $33.79^{\mathrm{ab}}$ \\
\hline Mean & $18.50^{\mathrm{B}}$ & $34.43^{\mathrm{A}}$ \\
\hline CV(\%) & 14.7 & 15.68 \\
\hline Means within a column followed by the same letter and those without letter designation are not significantly different at 5\% level
\end{tabular}
of significance

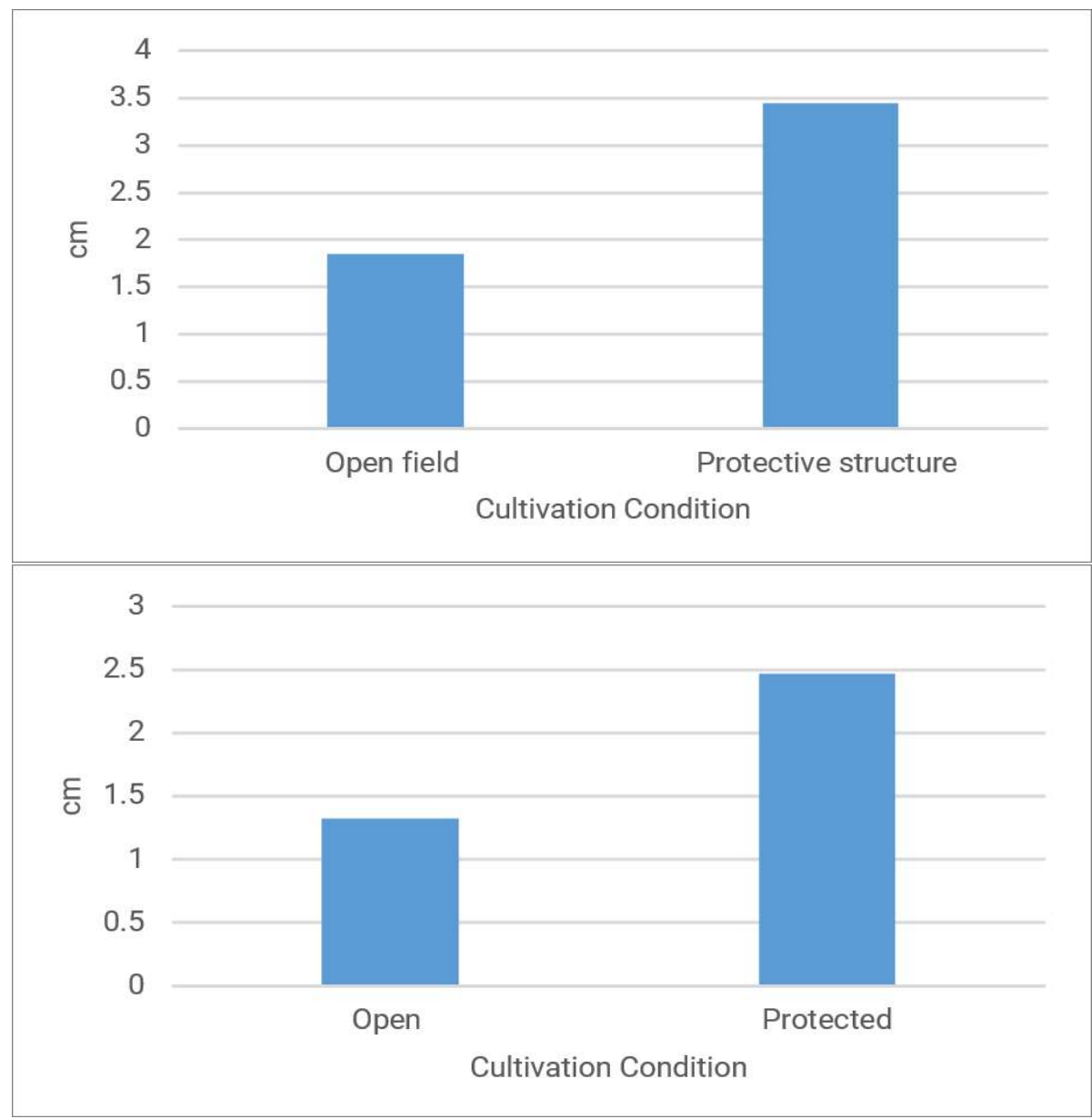

Figure 2. Comparison mean polar and equatorial diameter of fruits between of cultivation conditions regardless of chitosan-acetylsalicylic acid treatments 
Managing major diseases of tomato

\section{Evaluation of $\mathrm{SiO}_{2}$ Against Naturally Occurring Diseases and Yield of Tomato}

Effect of SiO2 and Cultivation Condition on Disease Ratings Incidence and Disease Severity Rating

In SIO2 trial, only bacterial wilt was observed infecting the plants but root samples were also examined for nematodes. SiO2 showed no significant effect on bacterial wilt incidence and disease severity. The cultivation condition, however had an effect. Plants grown inside protective structure had lesser bacterial wilt incidence $(37.1 \%$, Figure $3 a$ ) compared to plants outside $(68.4 \%)$ but the disease severity rating per plant did not vary significantly (Figure $3 b$ ).

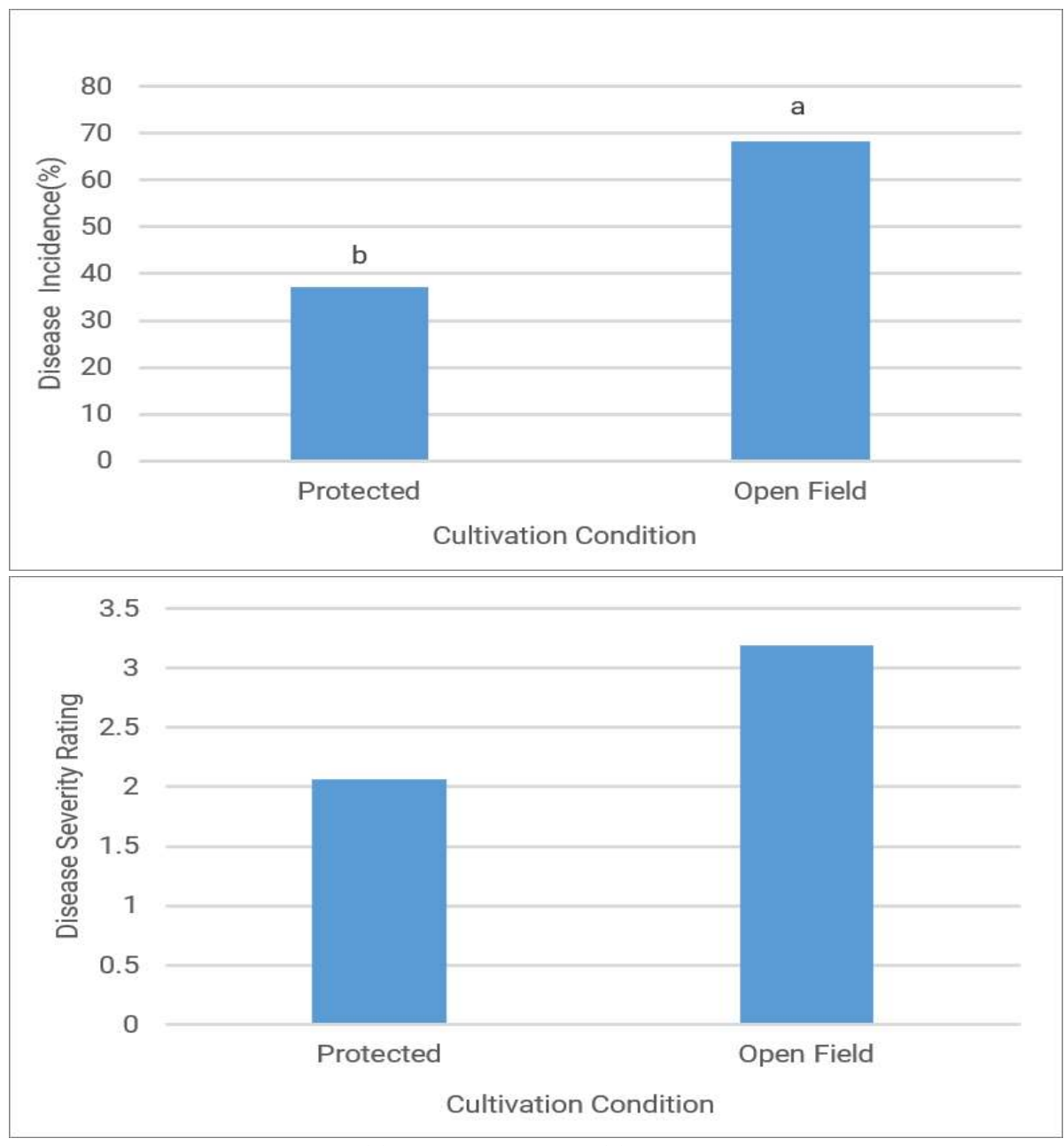

Figure 3. Bacterial wilt incidence (a) and severity rating (b) between open and protected cultivation, regardless of SiO2 treatments 
Five plant parasitic nematodes were extracted from the rhizosphere of tomato plants in the open field, namely: Rotylenchulus, Hemicycliophora, Helicotylenchus, and Xiphinema and root knot nematode, Meloidogyne incognita (Figure 4). The same nematodes were also recorded under structure except Hemicycliophora (Figure 5). Among the nematodes, Rotylenchulus sp. was the most abundant whose population was highest (mean of 45.5 nemas per $300 \mathrm{~g}$ soil) in untreated plots in open field cultivation and in plots sprayed with SiO2 (63 nemas per $300 \mathrm{~g}$ soil) under protective cultivation. The population of Rotylenchulus were generally higher in the soil under structure while the other nematodes were generally lower in the open field.

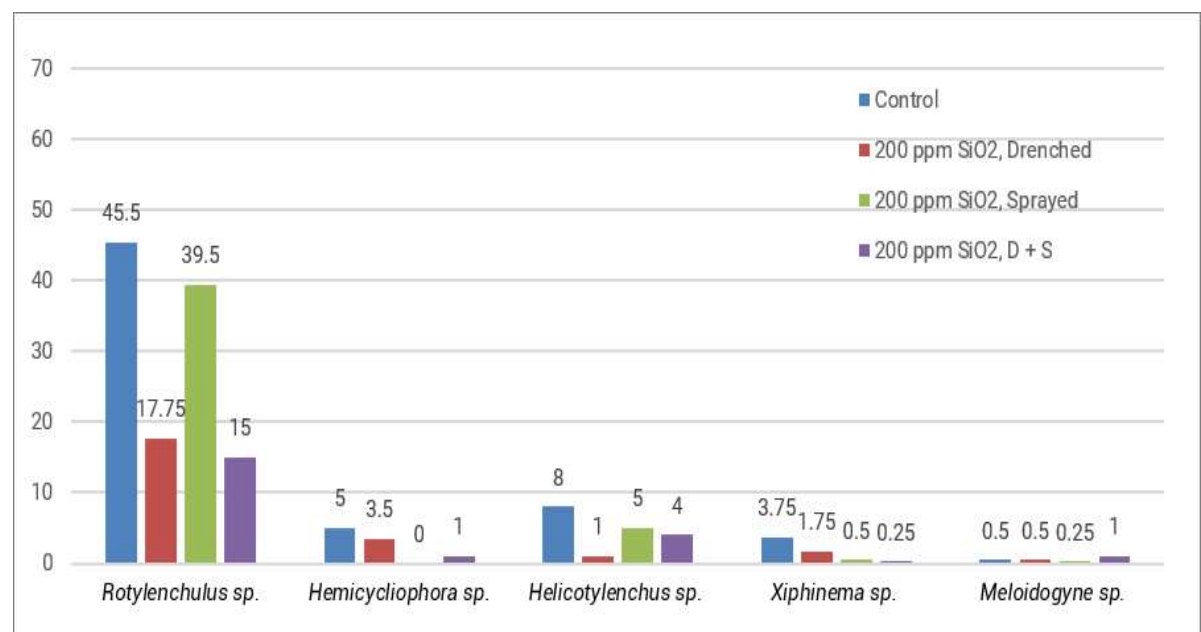

Figure 4. The nematodes extracted from $300 \mathrm{~g}$ of soil sample in the rhizosphere of tomato plants grown in the open field, treated $\mathrm{SiO} 2$ with different application methods

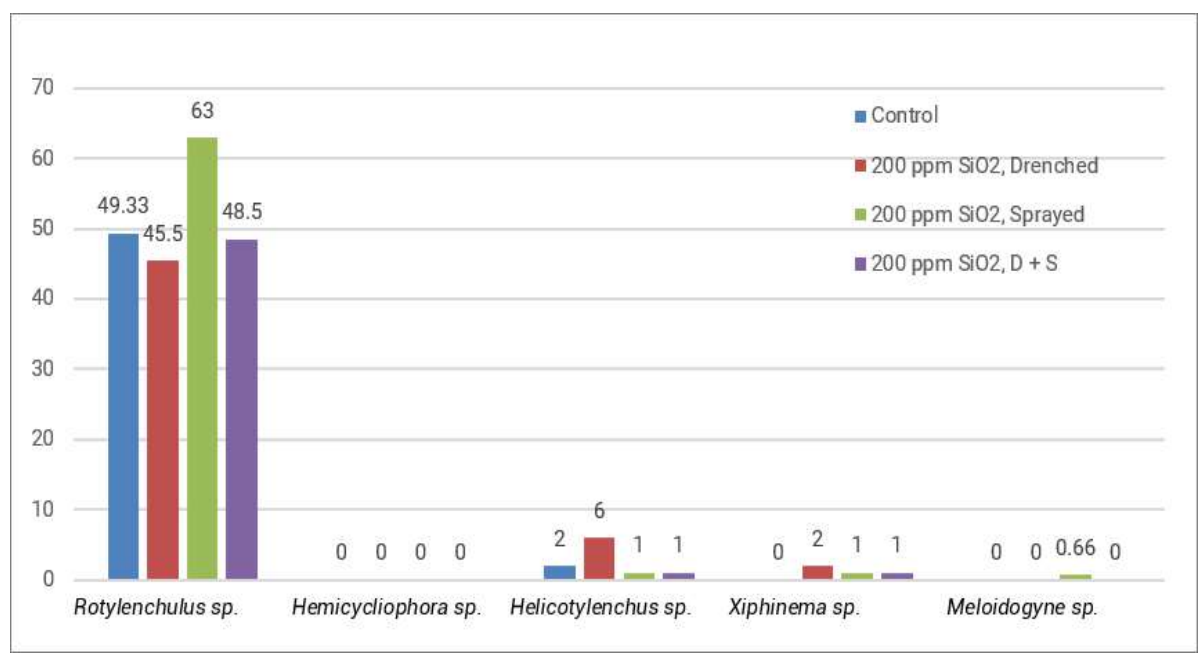

Figure 5. The nematodes extracted from $300 \mathrm{~g}$ of soil sample in the rhizosphere of tomato plants grown in under protective structure, treated $\mathrm{SiO} 2$ with different application methods 
Managing major diseases of tomato

When the population of Rotylenchulus (the nematode with highest population) was compared between $\mathrm{SiO} 2$ treatments, the number was evidently lower in $\mathrm{SiO} 2$ drenched plants grown under structure (17.75) and drenched plus sprayed (15) compared to untreated soil and SiO2-applied as spray to plants, particularly in the open field (Figure 6). This was not observed in plants under protected cultivation.

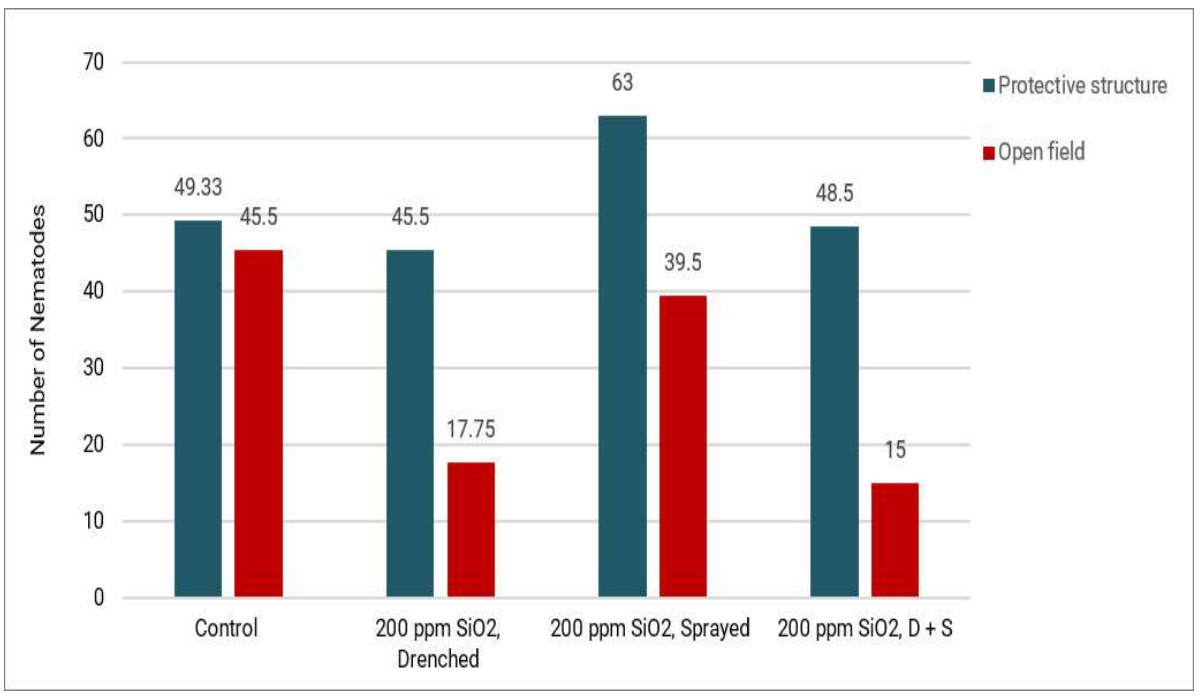

Figure 6. Average number of Rotylenchulus sp. recorded from $300 \mathrm{~g}$ soil samples

Effect of SiO2 treatments and cultivation condition on yield

Plants grown under protective cultivation significantly produced more fruits than in the open field. Plants under the protected structure also had much higher marketable fruit weight compared to those in the open field with 22.97 and 5. 56 tons per ha respectively (Figure 7).

The SiO2 treatments had no significant effect on yield when compared to the control. The highest marketable fruit yield was from plants sprayed with $\mathrm{SiO} 2$ with an average weight of 16.18 tons per ha but this was not significantly different from the untreated plants (Table 4). The $\mathrm{SiO} 2$ treatments also had no effect on the number of fruits in one replicate plot $\left(9 \mathrm{~m}^{2}\right.$ area). The non-significant effect on yield could be due to inclement weather which occurred towards the end of the cropping period due to typhoon Ruby.

The first trials demonstrate that 200ppm chitosan, acetyl salicylic acid, streptomycin and their combination can reduce bacterial wilt incidence and increase yield of tomato under protected cultivation, with chitosan-Acetylsalicylic acid as the most effective treatment. Borines et al 2015 found the direct inhibitory property of chitosan against $R$. solanacearum in vitro and $200 \mathrm{ppm}$ concentration was the most effective concentration in reducing bacterial wilt severity in inoculated tomato plants maintained in the screenhouue. The ineffectiveness of 
Borines et al

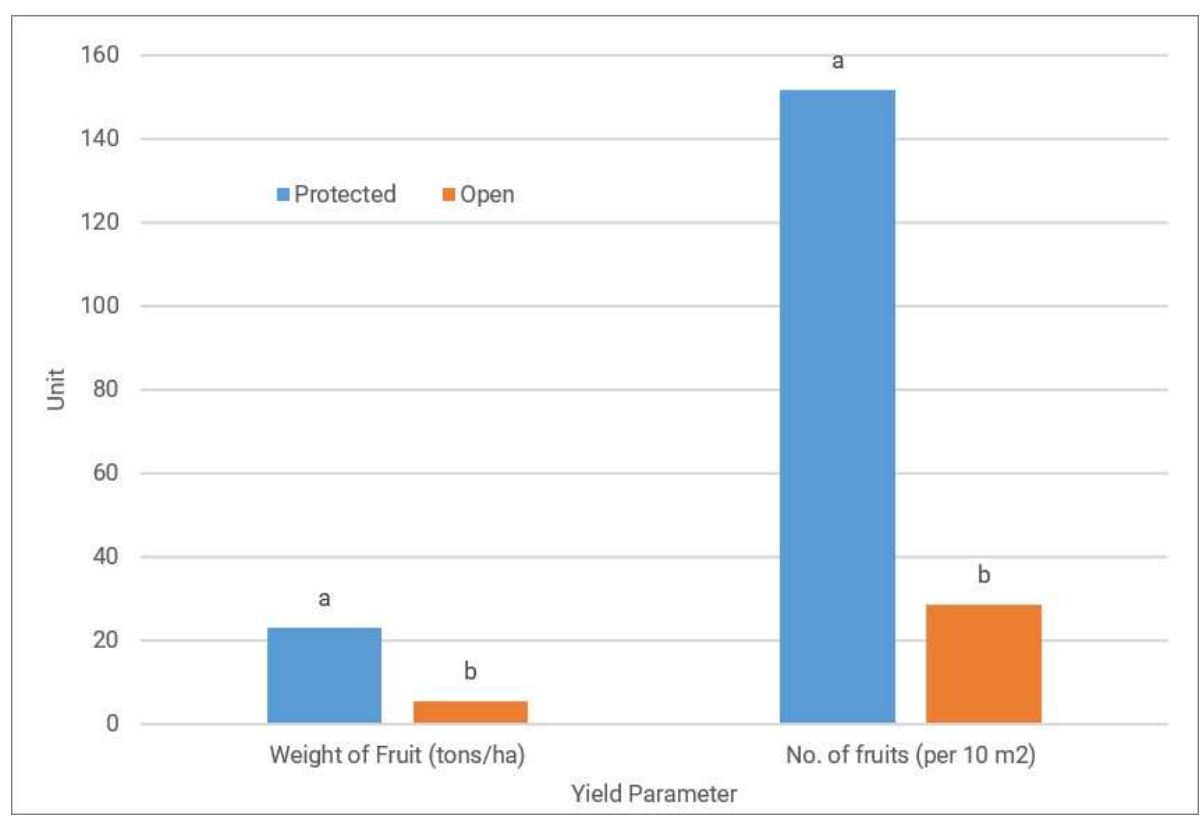

Figure 7. Marketable fruit weight (tons/ha) and number of fruits per $10 \mathrm{~m} 2$ area between tomatoes grown under open and protected cultivation

SiO2 did not protect plants from bacterial wilt infection but had reduced the nematode count in the roots, particularly Rotylenchulus $\mathrm{sp}$. which was the most abundant nematode found. In the second trial reduction in nematode count may be cause of increased yield in plants treated with $\mathrm{SiO} 2$. The effectiveness of $\mathrm{SiO} 2$ in protecting plants against bacterial wilt is reported to be selective depending on host genotype. Dannon \& Wydra (2004) found that Silicon showed differences in protecting plants against bacterial wilt. The wilt incidence in silicon-treated plants of genotype $\mathrm{L} 390$ reached $100 \%$ at 13 days post-inoculation (dpi), while in genotype King Kong2, plant death was retarded by 6 days, with $20 \%$ reduction of final wilt incidence. It could be that the variety used in the current study "Diamante Max" is really very susceptible to the disease such that the $\mathrm{SiO} 2$ treatment had not been able to induce resistance in the plants. The susceptibility of "Diamante Max" to the strain of the bacterium existing in the experimental area was reflected in the very high disease incidence (as high as $68.38 \%$ ) in open field cultivation.

Two hundred ppm SiO2, applied as drench and drench+spray, however was able to reduce nematode count in the tomato rhizosphere. A similar result was observed by Dugui-Es et al (2010) in cucumber inoculated with root knot nematode. At 200 ppm, one application of Silicon both on the leaves and roots significantly reduced the number of galls in inoculated plants. This was comparable to the same concentration applied continuously on the roots and at higher concentration (400ppm) applied continuously on the leaves and on the roots. In a similar study in cucumber infested with root knot nematode, the application of Silicon at the rate of $200 \mathrm{ppm}$ significantly increased the marketable yield compared to the higher rate of Silicon (400ppm, Dugui-Es et al 2010). 
Managing major diseases of tomato

Protected cultivation still proved effective in reducing bacterial wilt incidence in both experiments with supported the earlier findings by Borines et al (2016). It's potential to protect crops against bacterial wilt is further enhanced by the application of chitosan and acetylsalicylic acid, most especially the combination of these treatments.

\section{CONCLUSION/IMPLICATION}

Two hundred ppm chitosan, acetylsalicylic acid and their combination had reduced bacterial wilt incidence and increased the yield of tomato under protected cultivation, but not in the open field. SiO2 on the other hand was not able to reduce bacterial wilt incidence in tomato but had reduced the nematode count in the roots, particularly when drenched. Another study may be conducted with the addition of sticker to chitosan and acetylsalicylic acid spray to plants in open field cultivation of tomato so that they will not be washed out during rains.

\section{ACKNOWLEDGMENT}

The authors wish to thank the ACIAR/PCAARRD Philippine Horticulture Program, particularly the Australian Centre for International Agricultural Research for the Research Funds. Special thanks is also given to the Department of Horticulture Visayas State University through Dr. Zenaida Gonzaga for providing the experimental area where the trials were conducted.

\section{REFERENCES}

Agrios GN. 2012. Plant Pathology (3rd edn) (pp803). Academic Press. NY

Algam SAE, Xie GL, Li B, Yu SH, Su T \& Larsen J. 2010. Effects of Paenibacillus strains and chitosan on plant growth promotion and control of Ralstonia wilt in tomato. Journal of Plant Pathology 92(3):593-600

Arkipelago.2016.RegionVIII:EasternVisayas.https://kapuluanngpilipinas.wordpre ss.com/2016/05/16/region-viii-eastern-visayas/

Ait Barka E, Eullaffroy P, Clément C \& Vernet G. 2004. Chitosan improves development and protects Vitis vinifera L. against Botrytis cinerea. Plant Cell Reports 22(8):608-614

Amborabe BE, Bonmort J, Fleaurat-Lessard F \& Roblin G. 2008. Early events induced by chitosan on plant cells. Journal of Experimental Botany 59(9):2317-2324

Ayana G, Fininsa C, Ahmed S \& Wydra K. 2011. Effects of soil amendment on bacterial wilt caused by Ralstonia solanacerum and tomato yields in Ethiopia. Journal of Plant Protection Research 51(1):72-73

Benhamou N. 1992. Ultrastructural detection of $\beta-1,3-$ glucans in tobacco root tissues infected by Phytophthora parasitica var. nicotianae using a goldcomplexed tobacco $\beta$-1, 3-glucanase. Physiological and Molecular Plant Pathology 41(5):351-357

Borines LM, Gonzaga ZC, Capuno OB, Gerona RG, Lusanta DC, Dimabuyu HB, Vega MLP \& Rogers GS. 2016. Diseases commonly affecting vegetables in Eastern Visayas, Philippines, and their incidence under protective structure and in the open field. Acta Horticulturae 1128:117-123 
Borines LM, Sagarino RM, Calamba RB, Contioso MA, Jansalin JGF \& Calibo CL. 2015. Potential of chitosan for the control of tomato bacterial wilt caused by Ralstonia solanacearum (Smith) Yabuuchi et al. Annals of Tropical Research 37(2):57-69

Champoiseau G, Jones JB \& Allen C. 2009. Ralstonia solanacearum race 3 biovar 2 causes tropical losses and temperate anxieties. Online. Plant Health Progress doi:10.1094/PHP-2009-0313-01-RV

Chibu $\mathrm{H}$ and Shibayama H. 1999. Effects of chitosan applications on the early growth of several crops. Report of Kyushu Branch of the Crop Science Society of Japan 65:83-87

Dannon EA and Wydra K. 2004. Interaction between silicon amendment, bacterial wilt development and phenotype of Ralstonia solanacearum in tomato genotypes. Physiological and Molecular Plant Pathology 64:233-243

Datnoff LE and Rodrigues FA 2005. The Role of Silicon in Suppressing Rice Diseases. APSnetFeatures. doi:10.1094/APSnetFeature-2005-0205

Dugui-es C, Pedroche N, Villanueva L, Galeng J \& De Waele D. 2010. Management of root knot nematode, Meloidogyne incognita in cucumber (Cucumis sativus) using silicon. Communications in Agricultural and Applied Biological Sciences 75(3):497-505

El Ghaouth A, Arul J, Wilson C \& Benhamou N. 1994. Ultrastructural and cytochemical aspects of the effect of chitosan on decay of bell pepper fruit. Physiological and Molecular Plant Pathology 44(6):417-432

El Hassni M, El Hadrami A, Daay F, Cherif FM, Ait Barka E \& El Hadrami I. 2004. Chitosan, antifungal product against Fusarium oxysporum f. sp. albedinis and elicitor of defence reactions in date palm roots. Phytopathologia Mediterranea 43(2):195-204

Elphinstone JG, \& Hartman GL. 1992. Advances in the control of Pseudomonas solanacearum race 1 in major food crops. In Hayward AC and Hartman GL (eds) Bacterial Wilt: The Disease and its Causative Agent, Pseudomonas solanacearum (pp157-177). Biddles Ltd. Guildford UK

Fauteux F, Remus-Borel W, Menzies JG \& Belanger RR. 2005. Silicon and plant disease resistance against pathogenic fungi. FEMS Microbiology Letters 249(1):1-6

Gonzaga ZC, Capuno OB, Loreto MB, Gerona RG, Borines LM, Tulin AT, Mangmang JS, Lusanta DC, Dimabuyu HB \& Rogers GS. 2013. Low-cost protected cultivation: enhancing year-round production of high-value vegetables in the Philippines (pp123-137). In Oakeshott J and Hall D (eds) Smallholder HOPES horticulture, people and soil (pp298)

Harada J, Arima S, Shibayama H \& Kabashima R. 1995. Effect of chitosan application on growth and seed yield of soybean. Marine \& Highland Bioscience Center Report 2:15-19

Hayward AC. 1991. Biology and epidemiology of bacterial wilt caused by Pseudomonas solanacearum. Annual Review of Phytopathology 2:65-87

Lafontaine JP and Benhamou N. 1996. Chitosan treatment: an emerging strategy for enhancing resistance of greenhouse tomato plants to infection by Fusarium oxysporum f. sp. radicis-lycopersici. Biocontrol Science and Technology 6(1):111-124 
Managing major diseases of tomato

Li X, Wang RX, Chen WG, Huang G \& Xie, L. 2008. Antibacterial activity of chitosan solution against Xanthomonas pathogenic bacteria isolated from Euphorbia pulcherrima. Carbohydrate Polymers 72(2):287

Modina IM, Calibo, CL \& Borines LM. 2009. Antimicrobial property of chitosan and induction of systemic acquired resistance for the control of rice bacterial blight caused by Xanthomonas oryzae pv. oryzae (Swings et al.). Annals of Tropical Research 31(1):69-89

Momol MT, Mitchell DJ, Rayside PA, Olson SM \& Momol EA. 2000. Plant essential oils as potential biofumigants for the management of soilborne pathogens of tomato. Phytopathology 90:S127-S127

Niño M. 2009. Pathogenicity, Characterization and Identification of a bacterium causing heart rot of abaca and its control through elicitors of resistance (Undergraduate thesis) (pp80). Visayas State University. Visca, Baybay, Leyte

Piamonte RT. 2010. Antifungal Property of Chemical Elicitors and linduction of Systemic Acquired Resistance (SAR) for the Control of Rice Blast Caused by Pyricularia grisea Sacc (MS thesis) (pp89). Visayas State University, Visca, Baybay City, Leyte

Rabea El, Badawy MEI, Sterbaut W \& Stevens CV. 2009. Chemically Modified Chitosans as Antimicrobial Agents against Some Plant Pathogenic Bacteria and Fungi. European Polymer Journal 45:237

Romanazzi G, Nigro F, Ippolito A, Di Venere D \& Salerno M. 2002. Effects of pre-and postharvest chitosan treatments to control storage grey mold of table grapes. Journal of Food Science 67(5):1862-1867

Soleimani MJ and Kirk W. 2012. Enhancing resistance against Alteranaria alternata causing potato brown leaf spot disease by using some plant defense inducers. Journal of Plant Protection Research 52(1):83-90

Vruggink H. 1970. The effect of chitin amendment on actinomycetes in soil and on the infection of potato tubers by Streptomyces scabies. Netherlands Journal of Plant Pathology 76(5):293-295 